Original Research Paper

\title{
Pelatihan Psychological Self Care dan Anger Management pada Remaja yang Tinggal di Panti Sosial Marsudi Putra Paramita Mataram, NTB
}

\author{
Emmy Amalia ${ }^{1 *}$, Dyah Purnaning1, Umu Istikharoh ${ }^{1}$ \\ ${ }^{I}$ Fakultas Kedokteran, Universitas Mataram, Mataram, Indonesia.
}

https://doi.org/10.29303/jpmpi.v3i2.1129

Sitasi: Amalia, E., Purnaning, D \& Istikharoh, U. (2021). Pelatihan Psychological Self Care dan Anger Management pada Remaja yang Tinggal di Panti Sosial Marsudi Putra Paramita Mataram, NTB. Jurnal Pengabdian Magister Pendidikan IPA 4(4)

Article history

Received: 02 Oktober 2021

Revised: 20 Oktober 2021

Accepted: 07 November 2021

*Corresponding Author:

Emmy Amalia, Fakultas

Kedokteran, Universitas

Mataram, Mataram, Indonesia; Email:

emmy.amalia.ea@gmail.com

\begin{abstract}
WHO menyebutkan, remaja adalah salah satu kelompok umur yang rentan mengalami gangguan mental. Terlebih masa remaja merupakan waktu dimana banyak perubahan dan penyesuaian terjadi baik secara psikologis, emosional, maupun finansial. Banyak penelitian menunjukkan bahwa masalah perkembangan mental emosional remaja yang tinggal panti sosial secara bermakna lebih banyak dibandingkan dengan remaja yang diasuh orangtua kandung, cenderung memiliki konsep diri negatif, dan beresiko lebih tinggi terhadap terjadinya masalah perilaku. Kegiatan ini terdiri atas dua aktivitas. Aktivitas pertama berupa pemberian pelatihan psychological self care dan aktivitas kedua berupa pelatihan anger management, yang masing-masing akan dilakukan selama satu hari penuh. Berdasarkan data laporan PSMP Paramita tahun 2018, jenis kenakalan remaja semakin meningkat. Kenakalan yang menjadi sorotan adalah kenakalan yang menjurus pada permasalahan sosial seperti pencurian, pemerkosaan, pencabulan anak di bawah umur, pemakaian NAPZA, korban kekerasan, korban trafficking, dan permasalahan sosial yang kompleks lainnya. Jumlah anak dan remaja yang mendapat pelayanan sepanjang tahun 2018 sendiri total mencapai 240 orang; dan sebagian besar termasuk dalam kategori kelompok umur remaja. Diperlukan keterlibatan profesional kesehatan jiwa untuk mengatasi berbagai permasalahan mental yang terjadi pada remaja yang tinggal di PSMP Paramita. Bentuk keterlibatan professional kesehatan jiwa sebaiknya lebih bersifat selfempowerment, sehingga para remaja tersebut mampu melakukan secara mandiri cara-cara mengatasi masalah psikososial yang dialami dan tidak hanya bergantung pada layanan kesehatan sekunder. Oleh sebab itu, tim PPM bermaksud melakukan pelatihan Psychological Self Care dan Anger Management kepada para remaja yang tinggal di PSMP Paramita Mataram, NTB.
\end{abstract}

Keywords: psychological self care; Remaja; self empowerment

\section{Pendahuluan}

Menurut WHO, remaja adalah penduduk dalam rentang usia 10-19 tahun. Menurut Peraturan Menteri Kesehatan RI Nomor 25 tahun 2014, remaja adalah penduduk dalam rentang usia 10-18 tahun dan menurut Badan Kependudukan dan Keluarga Berencana Nasional (BKKBN) rentang usia remaja adalah 10-24 tahun dan belum menikah. Jumlah kelompok usia 10-19 tahun di
Indonesia menurut Sensus Penduduk 2010 sebanyak 43,5 juta atau sekitar $18 \%$ dari jumlah penduduk. Di dunia diperkirakan kelompok remaja berjumlah 1,2 milyar atau $18 \%$ dari jumlah penduduk dunia (WHO, 2014).

WHO menyebutkan, remaja adalah salah satu kelompok umur yang rentan mengalami gangguan mental. Terlebih masa remaja 
merupakan waktu dimana banyak perubahan dan penyesuaian terjadi baik secara psikologis, emosional, maupun finansial. Sayangnya, persoalan kesehatan mental masih dianggap kurang penting dibandingkan kesehatan fisik (WHO, 2014).

Gangguan mental, karena gejalanya tidak seperti penyakit fisik, acapkali terlambat disadari. Padahal di Indonesia, jumlah penderitanya terbilang tidak sedikit. Berikut ini contoh beberapa fakta yang terkait gangguan mental pada remaja di Indonesia:

a. Separuh dari penyakit mental bermula sejak remaja, yaitu di usia 14 tahun. Menurut WHO, banyak kasus yang tidak dapat tertangani sehingga bunuh diri akibat depresi menjadi penyebab kematian tertinggi pada remaja usia 15-29 tahun.

b. Prevalensi gangguan mental emosional pada remaja berumur lebih dari 15 tahun adalah sebesar 9,8\%. Angka ini meningkat dibandingkan tahun 2013 yaitu sebesar 6\% (Riskerdas, 2018).

c. Peningkatan jumlah pasien gangguan jiwa di Indonesia disebabkan oleh pesatnya pertumbuhan hidup manusia, serta meningkatnya beban hidup, terutama yang dialami masyarakat urban (Kemenkes, 2018).

Gangguan mental pada remaja, seringkali berawal dari respon yang salah dalam menghadapi masalah, sehingga timbul stres. Stres bukanlah sesuatu yang akan hilang dengan sendirinya. Menurut survey tahun 2018, mayoritas masyarakat Indonesia mengaku lebih memilih mengatasi stres secara mandiri. Hanya 1 dari 5 orang atau $20 \%$ responden saja yang meminta bantuan tenaga profesional (psikolog atau psikiater). Padahal cara berespon yang kurang tepat terhadap stres berpotensi menimbulkan gangguan kondisi mental lebih lanjut.

Kesehatan mental memegang peran penting pada remaja. Proses transisi pada masa remaja, yang ditandai dengan terjadinya perubahan fisik, hormon, kemampuan kognitif, emosi, dan perilaku, pada dasarnya sudah menjadikan remaja sebagai kelompok umur yang mempunyai faktor resiko besar mengalami gangguan mental. Jenis masalah kesehatan mental yang umum terjadi pada remaja terutama adalah depresi dan kecemasan (gangguan mental emosional). Dalam beberapa kasus, bunuh diri juga merupakan akibat dari masalah kesehatan mental yang tidak tertangani dengan baik sebelumnya.

Menurut Psikolog Erik Erikkson, pada usia 11 - 18 tahun (remaja), seseorang berada pada fase perkembangan identitas vs difusi peran. Pada kelompok usia ini, individu sedang gencar mencari identitas ego, sehingga pada masa ini banyak perilaku meniru yang dilakukan remaja dalam rangka membentuk identitas yang sedang dibangunnya. Individu dapat meniru dari tokoh idolanya, orang yang lebih tua, teman sebaya, dan pada era digital saat ini, individu dapat meniru dari berbagai hal yang dilihatnya di internet. Apabila hal-hal yang ditiru berdampak negatif bagi kesehatan mental, maka individu tersebut juga berpotensi mengembangkan sifat-sifat negatif yang akan terus dibawanya selama kehidupan masa dewasanya.

Pentingnya keberhasilan perkembangan selama periode remaja dan konsekuensinya terhadap perkembangan dan kesehatan dimasa dewasa membuat isu tentang perkembangan mental emosional remaja menjadi hal yang perlu mendapat fokus perhatian (Septiani N., 2013). Salah satu faktor utama yang mempengaruhi kesehatan mental emosional pada anak dan remaja adalah faktor lingkungan tempat tinggal dan kondisi kesehatan mental orang tuanya. Banyak penelitian juga menunjukkan hasil bahwa masalah perkembangan mental emosional anak yang tinggal panti asuhan secara bermakna lebih banyak dibandingkan dengan anak yang diasuh orangtua kandung (Riyadi et al, 2014). Penelitian lain menyatakan bahwa sebagian besar anak yang tinggal di panti asuhan cenderung memiliki konsep diri negatif dan beresiko lebih tinggi terhadap terjadinya masalah perilaku (Oktafia, 2018). Namun demikian, pada keadaan seorang anak atau remaja tidak dapat diasuh oleh orang tua kandung maupun keluarga dekat, maka diperlukan panti asuhan yang bertanggung jawab untuk memenuhi pemenuhan hak-hak mereka. Bagaimanapun, status perkembangan mental emosional anak dan remaja yang diasuh di panti asuhan lebih baik dibanding anak yang diterlantarkan (Riyadi, et al, 2015).

Terdapat 15 jenis panti sosial di Indonesia, beberapa di antaranya berfokus pada pelayanan dan bimbingan pada anak-anak dan remaja. Salah satu panti sosial tersebut adalah Panti Sosial Marsudi Putra (PSMP). Di Kota Mataram, NTB terdapat satu PSMP yang bernama PSMP Paramita. 
Panti sosial ini didirikan oleh Kementrian Kesehatan RI dan saat ini dikelola oleh Dinas Sosial Provinsi NTB. Jenis panti ini adalah panti sosial yang mempunyai tugas memberikan pelayanan dan rehabilitasi kepada anak dan remaja berstatus eks anak berhadapan dengan hukum $(\mathrm{ABH})$ yang berstatus offender dan defender untuk diberikan rehabilitasi sosial serta keterampilan sebagai bekal dalam kehidupan bermasyarakat dan dapat menjalankan fungsi sosialnya. Kategori $\mathrm{ABH}$ yang berstatus offender dan defender meliputi pelaku, saksi, maupun korban yang terlibat dalam pelanggaran hukum (Departemen Sosial RI, 2009).

Berdasarkan data laporan PSMP Paramita tahun 2018, didapatkan bahwa pada awalnya pelayanan rehabilitasi sosial yang diberikan kepada remaja yang masuk dalam kategori kenakalan, terbatas pada pelanggaran norma, seperti bolos sekolah, merokok, penggunaan NAPZA, berjudi, dan lain sebagainya. Sejalan dengan perkembangan waktu, jenis kenakalan semakin meningkat dan telah menjadi isu yang semakin mengkhawatirkan. Kenakalan yang menjadi sorotan adalah kenakalan yang menjurus pada permasalahan sosial seperti pencurian, pemerkosaan, pencabulan anak di bawah umur, pemakaian NAPZA, anak dan remaja korban kekerasan, korban trafficking, dan permasalahan sosial yang kompleks lainnya. Jumlah anak dan remaja yang mendapat pelayanan sepanjang tahun 2018 sendiri total mencapai 240 orang bayi, anak, dan remaja; dan sebagian besar termasuk dalam kategori kelompok umur remaja. Kondisi ini tentu perlu mendapat penanganan yang serius dari professional terkait, dalam hal ini salah satunya adalah penggerak kesehatan jiwa, karena sebagian besar masalah yang timbul adalah masalah mental emosional. Namun hingga saat ini, belum ada tenaga kerja di PSMP Paramita yang mempunyai latar belakang pendidikan khusus psikologi maupun psikiatri, walaupun sudah terdapat tenaga dari latar pendidikan kesehatan (perawat) dan pekerja sosial (PSMP Paramita, 2018). Oleh sebab itu, kerjasama antara lintas sektor, terutama dari sektor kesehatan jiwa, perlu untuk mulai dilakukan.

Terkait pengobatan dan terapi, seringkali kelompok umur anak dan remaja ini mengalami kesulitan mengakses pelayanan kesehatan maupun kesehatan mental, dikarenakan usia yang masih dianggap belum dewasa sehingga perlu ada wali yang dapat menjadi penanggung jawab, dan pada usia anak dan remaja ini kemampuan beradaptasi serta coping terhadap masalah juga belum cukup matur dibanding kelompok usia dewasa. Oleh sebab itu, adalah penting untuk meningkatkan pengetahuan dan skill remaja ini dalam menghadapi masalah kesehatan jiwa. Manfaat kegiatan ini adalah meningkatkan pengetahuan (knowledge) khalayak sasaran dan mitra, serta meningkatkan keterampilan khalayak sasaran dan mitra dalam melakukan strategi koping yang sehat dalam menghadapi dan menyelesaikan masalah.

Dari latar belakang yang telah dijelaskan di atas, diperlukan keterlibatan professional kesehatan jiwa untuk mengatasi berbagai permasalahan mental yang terjadi pada remaja yang tinggal di PSMP Paramita. Bentuk keterlibatan professional kesehatan jiwa sebaiknya lebih bersifat self empowerment, sehingga para remaja tersebut memahami dan mampu melakukan secara mandiri cara-cara mengatasi masalah psikososial yang banyak dialaminya saat ini maupun di masa yang akan datang, dan tidak hanya bergantung pada layanan kesehatan sekunder. Oleh sebab itu, tim PPM bermaksud melakukan pelatihan Psychological Self Care dan Anger Management kepada para remaja yang tinggal di PSMP Paramita Mataram, NTB. Target luaran dari kegiatan ini adalah meningkatnya pengetahuan dan keterampilan (skill) psikologis para remaja yang tinggal di PSMP Paramita Mataram, NTB dalam menghadapi stressor kehidupan.

Pelatihan psychological self care dan anger management ini merupakan pelatihan penting bagi setiap orang untuk dapat mengendalikan respon dan cara bersikap dalam menghadapi masalah, sehingga mencegah gangguan mental yang dapat terjadi sejak dini, terutama pada populasi yang rentan mengalami gangguan kejiwaan karena banyaknya faktor psikososial, seperti remaja dan anak terlantar yang tinggal di Panti Sosial Marsudi Putra Paramita ini. Dengan kemampuan yang lebih baik dalam menjaga kondisi psikologis dan kemarahan, anak dan remaja dapat terhindar dari dampak buruk kenakalan remaja seperti penyalahgunaan narkoba maupun gangguan fisik dan mental lain yang lebih berat. Selama ini pelatihan sejenis belum banyak dilakukan di Indonesia, terutama penyebabnya adalah kekurangtahuan akan kebutuhan ini di masyarakat, stigma terhadap gangguan jiwa, maupun 
keterbatasan tenaga kesehatan jiwa profesional untuk melatih.

Diharapkan pelatihan sejenis akan semakin banyak dilakukan di masa yang akan datang, terutama kepada kelompok-kelompok populasi beresiko, misalnya pada penghuni panti sosial,

\section{Metode}

Pada tahap persiapan, tim PPM melakukan studi pendahuluan dengan berkoordinasi dengan PSMP Paramita Mataram, NTB untuk mendata jumlah remaja yang terdaftar di PSMP Paramita saat ini. Selain itu tim PPM juga melakukan telusur pustaka untuk mengetahui kondisi remaja terlantar atau remaja bermasalah di NTB, apa jumlah masalah hukum atau pelanggaran terbanyak yang dialami, bagaimana status sosial ekonomi dan sosialnya, serta permasalahan kesehatan jiwa yang umumnya dihadapi.

Selanjutnya tim mensosialisasikan rencana pelatihan yang akan dilakukan dengan kantor PSMP Paramita Mataram, NTB. Pelatihan akan dilakukan selama dua hari sebagai berikut:

Hari 1: Pemberian Materi dan Pelatihan Psychological Self Care

Hari 2: Pemberian Materi dan Pelatihan Anger Management

Selesai sesi pelatihan, tim PPM akan membuka layanan pemeriksaan kesehatan jiwa secara privat jika ada peserta pelatihan yang ingin berkonsultasi lebih lanjut terkait kondisi psikologisnya.

\section{Hasil dan Pembahasan}

Pelaksanaan pengmas pelatihan psychological self care dan anger management yang seharusnya dijadwalkan dilangsungkan pada Bulan Juli 2021 sempat tertunda karena kondisi pandemi Covid-19 gelombang kedua yang melanda hampir seluruh wilayah Indonesia termasuk NTB. Di Panti Sosial Marsudi Putra Paramita sendiri, penghuni bergantian terinfeksi Covid-19 sehingga Panti sempat ditutup sementara waktu. Pelaksanaan kegiatan yang sebelumnya direncanakan dilakukan secara online sendiri, setelah dievaluasi lebih lanjut belum memungkinkan untuk dilakukan secara online karena kondisi keterbatasan alat online narapidana, dan lain-lain. Kepada para peserta pelatihan sebelumnya juga tetap dapat dilakukan pembinaan, dan juga tidak menutup kemungkinan dilakukan ToT (training of trainer) kepada peserta pelatihan sebelumnya agar dapat menjadi pelatih psychological self care dan anger management. termasuk handphone yang ternyata tidak dimiliki semua anak, serta kondisi perhatian penghuni yang sulit fokus untuk mendengarkan jika tidak langsung diberikan dengan tatap muka. Atas latar belakang inilah, akhirnya pelaksanaan pelatihan dilakukan pada tanggal 6-7 Oktober 2021 secara offline bertempat di Panti Sosial Marsudi Putra Paramita.

Acara dihadiri oleh 22 orang penghuni putra dan 18 orang penghuni putri dengan 4 orang pengasuh. Acara kegiatan dibagi menjadi beberapa termin dan dilakukan selama dua hari dengan jadwal sebagai berikut:

Hari pertama:

1. Pembukaan

2. Pemberian materi psychological self care dan praktek

3. Tanya jawab dan diskusi

4. Konsultasi perseorangan/pribadi

5. Penutup

Hari kedua:

1. Pembukaan dan review materi hari pertama

2. Pemberian materi anger management dan praktek

3. Tanya jawab dan diskusi

4. Konsultasi perseorangan/pribadi

5. Penutup

Pada pembukaan, setelah pemberian sambutan dan doa, acara dimulai dengan sharing dan berbagi pengalaman dengan kondisi emosi masing-masing peserta selama ini. Banyak peserta menceritakan kesulitannya dalam mengendalikan emosi selama ini, yang sering berujung pada konflik atau pertengkaran dengan orang lain, terutama keluarga, menyebabkan peserta keluar dari rumah, terlibat narkoba, putus sekolah, ataupun melakukan perbuatan-perbuatan melanggar hukum dan sejenisnya. Stressor atau sumber masalah utama mayoritas peserta juga berasal dari rumah, mulai dari sikap orang tua dan kondisi keluarga yang broken home, namun ada juga yang berasal dari lingkungan di luar rumah. Mayoritas peserta mengenal narkoba dari teman atau orang dekat, bahkan ada yang dari keluarga sendiri yang juga 
memakai narkoba. Acara sharing ini sendiri membutuhkan waktu hingga 45 menit.

Acara selanjutnya yang merupakan acara inti, adalah pemaparan materi tentang psychological self care (dan pada hari kedua tentang anger management). Peserta dipaparkan tentang pentingnya memberi dukungan psikologis dan self empowerment pada diri sendiri maupun kepada orang-orang di sekelilingnya yang ia ketahui. Dukungan psikologis dan self empowerment menggunakan pendekatan cara Capacitar, yang dapat digunakan sewaktu-waktu saat merasa lelah, bingung, cemas, atau merasa tertekan. Pendekatan ini dapat dilakukan untuk diri sendiri, maupun diajarkan kepada orang-orang di sekelilingnya. Yang menjadi tantangan adalah memadukan pendekatan ini dalam kehidupan sehari-hari sampai menjadi kebiasaan dan dapat otomatis dilakukan saat merasa lelah, bingung, atau merasa tertekan. Berikut adalah beberapa langkah psycholigical self care dengan pendekatan cara Capacitar:

\section{Latihan pernafasan}

Nafas adalah sumber kehidupan yang berfungsi untuk mengalirkan energi segar kedalam jaringan dan sel tubuh kita. Saat kita menghembuskan nafas, ketegangan dan toksin yang berkumpul di badan dapat terlepas keluar. Pola nafas berubah sejalan dengan perubahan perasaan, maka demikian sebaliknya, dengan mengubah cara kita bernafas, kita dapat mengubah perasaan dan kondisi fisik kita. Latihan pernafasan yang dianjurkan adalah pernafasan perut.

\section{Gerakan Tai Chi}

Empat gerakan dasar tai chi berikut berguna untuk melepaskan ketegangan dan kesakitan, menajamkan pikiran, dan menenangkan jiwa di saat susah. Gerakan ini dapat dilakukan di pagi hari, yang terdiri atas: gerakan goyang berirama, gerakan pancuran cahaya, gerakan membuka diri untuk menerima, dan gerakan terbang di udara.

\section{Pegangan jari untuk mengendalikan emosi}

Di setiap jari kita ada saluran atau meridian aliran energi yang berhubungan dengan organ tubuh dan emosi yang bersangkutan. Perasaan yang sangat kuat atau luar biasa bisa menyumbat atau menghambat aliran energi, yang mengakibatkan rasa sakit atau perasaan sesak di tubuh kita. Caranya, peganglah tiap jari satu persatu, dengan tangan yang lain selama 2-5 menit. Tarik nafas yang dalam, rasakan perasaan kuat atau perasaan yang mengganggu di dalam diri anda. Hembuskan nafasa secara perlahan dan lepaskan. Bayangkan perasaan-perasaan itu mengalir keluar dari ujung jari dan masuk ke dalam bumi.

4. Teknik mengetuk, suatu teknik untuk kebebasan emosional

Mengetuk atau menekan titik akupressur yang berhubungan dengan saluran atau meridian dimana energi mengalir ini dapat membantu membuka sumbatan energi tersebut dan mendukung aliran energi yang baik di dalam tubuh, mental, dan emosi. Tarik nafas dalam-dalam, ketuklah dengan 2 jari (telunjuk dan tengah) tangan kanan dan kiri bersama-sama pada titik-titik akupresur sebanyak 7-9 kali di titik dimana kedua alis dimulai; titik dimana alis berakhir, di samping sudut luar mata; titik dibawah kedua bola mata, pada tulang pipi; titik dibawah hidung (lakukan dengan satu tangan saja); titik dibawah mulut, pada dagu (gunakan satu tangan saja); titik $10 \mathrm{~cm}$ dibawah kedua ketiak; titik dibawah tulang leher, pada kedua sisi tulang dada.

\section{Pemegangan}

Pemegangan yang dilakukan adalah sangat ringan, tanpa tekanan, dan jika ada orang yang tidak suka dipegang karena trauma yang dialaminya, pemegangan ini dapat dilakukan di energi yang melingkupi badannya (tanpa menyentuh badan orang itu). Pemegangan dilakukan di area kepala (satu tangan di atas dahi, tangan yang lain di bagian bawah kepala), di area ubun-ubun (kedua ibu jari bertemu dan diletakkan pada tengah ubun-ubun, ujung-ujung jari diletakkan dengan lembut di bagian atas dahi), dan di bahu (kedua tangan diletakkan secara lembut di atas kedua bahu, tempat di badan yang berhubungan dengan kecemasan dan beban dalam hidup).

\section{Pijatan kepala, leher, bahu}

Titik-titik pijatan berpasangan, meliputi: kurang lebih 2,5 cm dibawah tungkai bahu (bagian luar) dimana lengan bertemu dengan bagian badan; diatas bagian dalam tulang belikat, kira-kira $5 \mathrm{~cm}$ dari tulang punggung; di atas bahu di pangkal bawah leher (otot trapezius); di kedua sisi otot bagian tengah leher; di kedua lekukan yang terletak di sisi bagian bawah kepala; dan di puncak kepala atau ubun-ubun. 
7. Pain drain (pengurasan rasa nyeri)

Letakkan telapak tangan kiri di bagian tubuh anda yang terasa tidak nyaman lalu hadapkan telapak tangan ke bawah, menjauh dari tubuh. Bayangkan semua rasa tidak nyaman ditarik/disedot oleh jari dan telapak tangan kiri dan dikembalikan ke bumi oleh jari dan telapak tangan kanan. Proses ini dapat lebih efektif jika kita dapat membayangkan bahwa jari dan telapak tangan kanan mampu memompa keluar semua ketidaknyamanan dari titik yang ada di jari dan telapak tangan kiri.

Letakkan telapak tangan kanan di bagian tubuh anda yang terasa tidak nyaman dan angkat telapak tangan kiri ke atas kepala menghadap ke atas untuk membawa masuk energi dari universal.

\section{Pal dan Gum}

Teknik Pal dan Gum terdiri dari 8 gerakan peregangan yang bertujuan untuk meredakan ketegangan, keseimbangan, dan membawa energi pada tubuh. Delapan gerakan tersebut meliputi: upholding the heavens, opening the bow, touching heaven and earth, looking behind you, swinging the truck and head, stretching backwards, stretching the legs and toes, punch with fists, dan akhirnya diakhiri dengan berteriak sekuatnya untuk melepaskan ketegangan yang terpendam. Setelahnya, kita dapat rileks sejenak dengan menarik nafas panjang dan menikmati sensasi rileks untuk beberapa saat.Keseluruhan siklus gerakan-gerakan ini dapat diulang beberapa kali sesuai kebutuhan.

Materi anger management mengajarkan bagaimana mengendalikan rasa marah dan apa yang harus dilakukan jika perasaan marah datang. Pada pemaparan materi, peserta diberikan edukasi terlebih dahulu bahwa setiap orang bisa merasa marah karena terdapat komponen-komponen biologis dan psikologis pada seseorang yang berperan terhadap timbulnya rasa marah. Sehingga sebenarnya marah adalah salah satu bentuk emosi normal yang dapat terjadi pada setiap orang. Namun mengendalikan dan bertindak tepat saat kita marah adalah hal yang penting, agar kita terhindar dari efek-efek merugikan akibat kemarahan, seperti terganggunya hubungan dengan orang lain, melakukan kekerasan pada diri sendiri atau orang lain, sampai terganggunya kesehatan fisik maupun mental dari diri sendiri. Peserta diajak untuk mulai terbiasa mengenali apa perasaan sebenarnya yang dialami saat ia merasa marah.
Marah dapat terjadi karena berbagai latar belakang: malu, kecewa, merasa dirugikan, tidak terima, diperlakukan tidak adil, sedih atau berduka, frustasi, dan lain-lain. Terdapat beberapa pendekatan yang dapat kita latih untuk diri sendiri agar perasaan marah yang kita rasakan tetap dibawah kontrol, sebagai berikut:

1. Berpikir sebelum bicara.

Pada momen dimana perasaan sedang panas, marah, mudah untuk mengatakan sesuatu yang pada akhirnya akan anda sesali kemudian. Oleh sebab itu, beri waktu untuk membuat perasaan lebih tenang terlebih dahulu, sehingga anda dapat berpikir lebih jernih, sebelum akhirnya berbicara. Beri kesempatan pada orang lain yang marah untuk melakukan hal ini juga.

2. Saat perasaan sudah lebih tenang, ekspresikan kemarahan dengan tepat.

Begitu anda merasa lebih tenang dan dapat berpikir jernih, ekspresikan kemarahan secara verbal, jelas, langsung, tanpa menyakiti orang lain atau berusaha mengontrol mereka. Misalnya dengan menyatakan: "saya marah, saya merasa kecewa, saya frustasi, karena....".

3. Lakukan olahraga atau aktivitas fisik.

Aktivitas fisik dapat mengurangi rasa stres yang seringkali pada akhirnya menimbulkan rasa marah. Kalau kita merasa rasa marah yang terus menguat, lakukan jalan cepat atau berlari, atau melakukan aktivitas fisik lain yang kita sukai.

4. Beri jeda waktu untuk diri sendiri.

Beri waktu jeda pada saat-saat tertentu, misalnya ditengah-tengah jadwal yang padat atau hectic, untuk diri sendiri, atau sekedar beristirahat siang/tidur sejenak.

5. Pikirkan/identifikasi masalah yang menyebabkan marah dan solusi terhadap rasa marah yang muncul.

6. Biasakan untuk melihat kemarahan dari kacamata "saya" (daripada menyalahkan lingkungan/orang lain).

Agar terbiasa berhenti menyalahkan orang lain atau lingkungan, biasakan untuk melihat apa yang terjadi pada diri sendiri saat marah. Misalnya "saya marah, saya kecewa, karena rencana itu tidak berlangsung sesuai yang saya harapkan", daripada menilai dengan cara "rencana tersebut tidak akan berjalan lancar 
dengan cara seperti itu".

7. Jangan menyimpan dendam.

Menyimpan kemarahan atau perasaan negatif yang lain, perlahan-lahan akan menggerogoti perasaan positif yang lain sehingga seringkali tanpa kita sadari kita sudah selalu diliputi perasaan negatif atau kemarahan dalam memandang hal-hal yang lain juga. Perlu dilatih kebiasaan melepaskan atau memaafkan yang benar-benar kita upayakan dari lubuk hati.

8. Gunakan humor untuk meredakan ketegangan/kemarahan.

Humor yang dapat kita lakukan adalah yang terkait kemarahan atau harapan kita sendiri yang sebetulnya tidak realistik. Untuk dapat sampai ke tahap ini, kita memang perlu menerima dulu bahwa kita marah karena alasan atau penyebab tertentu. Hindari humor yang bersifat menjelekkan orang lain atau berbau SARA.

9. Melatih teknik relaksasi.

Saat temperamen kita semakin meningkat, lakukan relaksasi dengan berlatih mengatur nafas dalam selama beberapa menit, atau dengan mengulang-ulang pikiran atau kata-kata tertentu yang menenangkan, misalnya "tenang, tenang, ini bukan masalah besar".

10. Mengetahui kapan harus minta bantuan lebih lanjut.

Bagaimanapun, melatih kemampuan mengendalikan kemarahan adalah suatu proses yang tidak dapat dilatih hanya sehari. Jika perasaan marah menjadi sulit anda kendalikan sendiri walaupun anda sudah berusaha melakukan teknik-teknik di atas, sampai mengganggu aktvitas sehari-hari, mengganggu hubungan dengan orang lain atau kondisi psikologis lebih lanjut, maka sebaiknya anda menemui psikiater atau psikolog terlebih dahulu untuk mendapat penanganan yang labih baik.

Acara selanjutnya setelah pemberian materi selesai, adalah diskusi dan latihan ulang terhadap teknik-teknik yang telah diajarkan. Para peserta tampak antusias dan mengajukan banyak pertanyaan. Pertanyaan yang paling banyak diajukan terutama meliputi teknis pelaksanaan langkah-langkah anger management di atas yang menurut beberapa peserta masih sulit dilaksanakan karena masalah-masalah yang ia hadapi lebih kompleks, dan penyebab marah ada terus setiap saat.

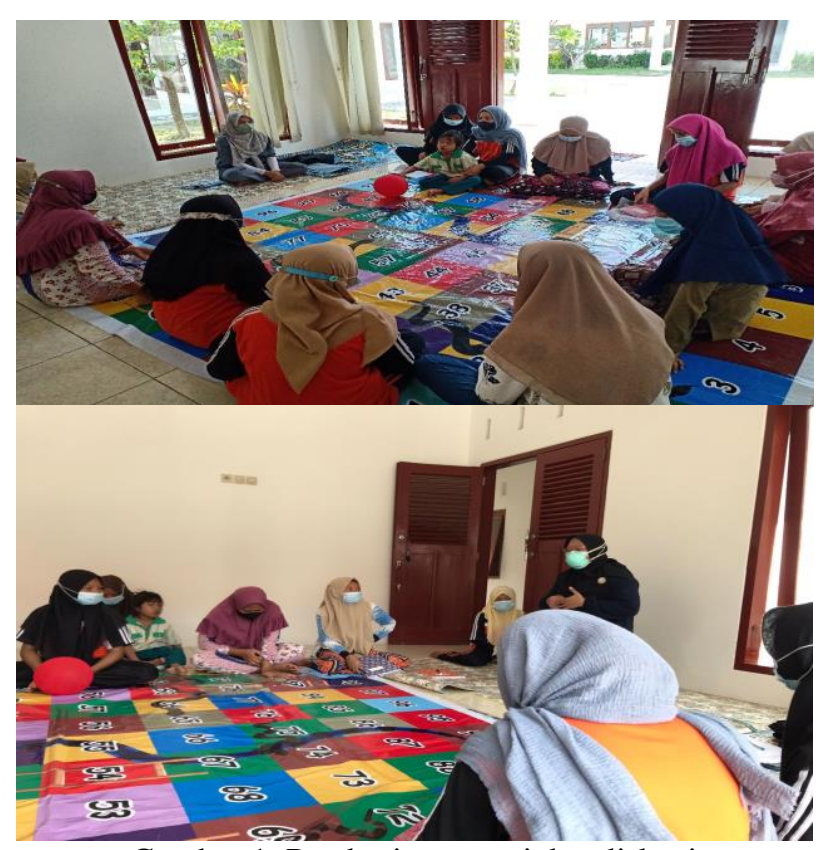

Gambar 1. Pemberian materi dan diskusi

Acara terakhir adalah memberi kesempatan peserta berkonsultasi secara pribadi, secara bergantian, untuk menceritakan keluhan atau kesulitan yang dihadapi peserta selama ini. Acara terakhir ini berlangsung kurang lebih selama satu jam setiap hari, pada hari pertama dan kedua.

\section{Kesimpulan}

Pelatihan Psychological self care dan anger management sangat penting untuk diadakan, terutama untuk komunitas atau populasi tertentu yang rawan menghadapai banyak masalah psikososial, termasuk anak dan remaja di panti sosial. Dengan kemampuan psychological self care dan anger management yang baik, individu jadi lebih dapat menghadapi masalah-masalah psikososial yang dihadapinya dengan lebih baik, sehingga mencegah resiko terjadinya gangguan mental yang lebih berat. Dengan metode berbasis self empowerment ini, manusia dikembalikan ke dalam kondisi kesejahteraan, yaitu kembali harmoni antara energi dari pusat energi tubuh, keseimbangan emosi, dan kondisi mental yang jernih, sehingga pada akhirnya kualitas hidup mereka menjadi lebih baik. Sebagai saran, kegiatan serupa perlu diberikan secara berkala agar peserta pelatihan tetap terlatih, dan selanjutnya peserta juga 
dapat kita didik menjadi pelatih juga, sehingga dapat mengajarkan teknik-teknik yang bermanfaat ini kepada orang lain di sekitarnya.

\section{Daftar Pustaka}

Astri, H. (2014). Kehidupan Anak Jalanan di Indonesia: Faktor Penyebab, Tatanan Hidup, dan Kerentanan Berperilaku Menyimpang. Aspirasi. Vol. 5(2)

Haryanti, D., Pamela, E, M., Susanti, Y. (2016). Perkembangan Mental Emosional Remaja di Panti Asuhan. Jurnal Keperawatan FIKKes Universitas Muhammadiyah Semarang. Vol. 4(2), p. 97-104

Kementerian Kesehatan RI (2018). Situasi Kesehatan Reproduksi Remaja. Pusat Data dan Informasi Kementerian Kesehatan RI. Jakarta: Kementerian Kesehatan RI.

Oktavia, N., A. (2018). Efektivitas Pelatihan Mindfulness dalam Menurunkan Kesepian Remaja di Panti Asuhan. Skripsi Fakultas Psikologi Universitas Sunan Ampel Surabaya. Diunduh dari http://digilib.uinsby.ac.id

PSMP Paramita. (2018). Laporan Kinerja PSMP Paramita Mataram Tahun 2018. Mataram: PSMP Paramita.

Riyadi, Rusmil, K., Effendi, S., H. (2014). Risiko Masalah Perkembangan dan Mental Emosional Anak yang Diasuh di Panti Asuhan Dibandingkan dengan Diasuh Orangtua Kandung. MKB. Vol. 46(2), p. 1-7

Suryanto, Herdiana, I., Chusairi, A. (2016). Deteksi Dini Masalah Psikologis Anak Jalanan pada Orang Tua Asuh di Rumah Singgah. Insan Jurnal Psikologi dan Kesehatan Mental. Vol. 1(2), p. 85-96

World Health Organization. (2014). Global Accelerated Action for The Health of Adolescents (AA-HA!): Guidance to Support Country Implementation. Jeneva 